\title{
Discussion on Innovation of Marketing Management of Electric Power Enterprises
}

\author{
Yuan Tian and Shang Chao \\ State Grid Jiangxi Electric Power Research Institute, Jiangxi Nanchang 330096
}

Keywords: Power; Marketing management; Innovation measures; Informatization

\begin{abstract}
With the reform and development of China's power market, power enterprises have been developing rapidly and the ever increasingly basic foundation has proposed higher requirements for the innovation of power marketing management while scientific and reasonable power marketing management should be based on guaranteeing the development moment of power enterprises' marketing. Because there are still some problems in power enterprises, and these problems are mainly how to establish a good image of power companies, explore new power market and improve enterprises' business efficiency. In order to make power enterprises develop better, power enterprises need to take new marketing management strategies and establish new marketing concepts so as to meet the market demand and have stronger development potential.
\end{abstract}

\section{Introduction}

In the development of China's socialist market economy, some success has been made in the market reform in various fields. Take the power industry as an example, during the development of power enterprises, power marketing management is a very important task, and whether power marketing management is scientific determines the effect of power marketing behaviors to a large extent, which is also an important part of power enterprises' core competitiveness. However, there are deviations in many of China's power enterprises' understanding of marketing management, and they still have the concept and awareness of previous administration management mode. They fail to innovate management thoughts and modes according to the new environment of power enterprises' operation after the market reform and new demands of power marketing, which makes some power enterprises lag behind in marketing management. Not only their management level cannot be improved, they may also lead to the regression of marketing management because they cannot adapt to the market environment and complicated demands of power marketing management in the new era and bring great loss to enterprises' economic and social benefits. In order to effectively solve the above questions, it is necessary to make the management concept keep pace with the times and enhance innovation of power marketing management from various aspects.

\section{Power Marketing}

Electric goods are a kind of special commodity. Therefore, the power market is also a special market. Subsequently, power marketing is a special marketing activity.

Power Marketing is a Highly Serviceable Business, which is determined by the characteristics of the power market. The public nature and basic status of the power industry determine the service nature of power marketing. From national economy to people's daily life, power marketing must provide customers with quality, reliable and sufficient power energy no matter when and where. The unsecured nature of electrical goods makes the connection between power manufacturers and electricity customers very close.

Power Marketing is a Strongly Integral Business. The sales and distribution channels of the power market depend on the power grid, which integrates power plant, transmission lines, substation, power distribution and power usage into one. Each link of the production and sales channel connected by the grid is closely linked and indispensable, or the safe production and power commodity sales cannot be guaranteed, and social benefits and corporate efficiency will become an empty talk. 


\section{Current Status of China's Power Marketing}

The Concept of Marketing Management is Weak with Imperfect Department Mechanism. The concept of marketing management is weak. As the producer and operator of commodities, power enterprises aim to pursue the best economic benefits and take consolidating and developing the market as the basis for the survival and development of themselves. For a long time, power supply is in short, so that the entire power enterprises operate according to strict mode of planned economy, and depend on the government for development, policy for benefits and administrative means for management. From surfing the Internet to sales, each link of power enterprise and the demand and supply of power are regulated according to plan to make the production, supply and sales of power consistent with each other. Such overall situation causes the leaders and staffs have weak marketing management concept. With the completion of rural power grid transformation, power system reform and separation of plants and grid, it will be the key for China's power supply departments to improve the marketing concept, have good power marketing management, improve enterprises' benefits and realize rapid development in order to improve market competitiveness.

Power Sales Channels are Not Smooth and Power Supply Services Lag behind Users' Demands for Power. Electric power is a commodity that breaks monopoly and is oriented at introducing market competition at present. Besides, the power industry system reform with "separating factories and grid and bidding for surfing the Internet" has already become the path for China's power industry to the market. The fundamental task for the power in the market is high-quality services. For years, the "seller's market" with short supply of power supply enterprises makes power company staffs form the style of "hard to enter the door and doing things depending on others' mood". There is a lack of researches into the end-users with complete pre-sales and after-sales service system. The installation and reporting procedures are cumbersome, faults cannot be timely handled and in place, restricting the sales of power and affecting the normal development of the power market, forming a power sales market in which it is hard to sell and purchase with structural contradictions.

Grid Construction Lags Behind with No Transmission and No Availability of Power, Greatly Influencing Power Supply. Because the grid construction lags behind the power construction for a long time and sometimes, no electricity is available. For a long time, investment in grid construction is insufficient, urban grid is aging and rural grid is weak, thus power cannot be smoothly transmitted to any place with power demand, forming the situation that "power cannot be transmitted and power supply cannot be guaranteed".

\section{Innovative Measures in Electric Power Marketing Management}

Strengthening the Construction of Power Marketing Management Informatization Mode. At present, we are in an information age featured by the popularity and application of information technology. In China's power industry, power information construction has already received attention of the majority of power enterprises with a lot of human resources, materials and finance invested to support information construction. However, in terms of the current reality, the information level of many power enterprises in power marketing and management is relatively low, and the advantage of information technology cannot be fully utilized, which is largely related to the lack of a unified and perfect information management mode. Therefore, in the innovation of power marketing and management, the first step is to innovate management information mode.

To strengthen the improvement of management system adaptable to information marketing means and management means, it is better to effectively guide power enterprises to smoothly carry out marketing activities and relevant management activities in the information age and integrate information thought into human resource management and adjust management schemes from talent cultivation, work mechanism adjustment and management procedure optimization to ensure that full play can be given to information technology in power marketing management, improve the utilization rate and value of information resources so as to improve the efficiency of power marketing and management. 
Innovation of Marketing Idea of Electric Power Enterprises. China's power enterprises need to establish a good corporate marketing management, which first requires power enterprises to establish their marketing strategies based on market demands, enhance demand management in marketing, grasp the market development trend, evaluate the power market potential and future market with some procedures and timely formulate and adjust power generation and sales as well as other production and operation targets based on this. Besides, timely adjust power enterprises' marketing strategies and effectively expand market. Secondly, power enterprises need to establish user-oriented new concept in marketing, focus on users in everything and take users' demands as the purpose with the emphasis on grid transformation and establishment. Establish the concept that grid construction should meet users' power usage, improve power supply and distribution network to meet the demand of the majority of users. Meanwhile, use advanced communications, network and computer technology to provide users with efficient and comprehensive quality services. Meanwhile, use strict specification management to monitor various businesses to provide high-quality and cheap power commodities and reduce consumers' burden.

Innovation of Marketing Service for Electric Power Enterprises. China's power enterprises need to establish good corporate marketing and management image. First of all, power enterprises need to make full use of advertisements to promote themselves, make power uses understand the marketing strategies of power enterprises, enhance communication with power uses and formulate a series of promotional measures according to market demand. Secondly, in order to improve power quality and power supply reliability, China's power enterprises need to enhance grid transformation and establish perfect grid facilities to ensure the security and stability of power for users. Meanwhile, increase the transparency of customers' power and make power marketing strategies recognized by the market so that power enterprises can expand more power market.

\section{Conclusion}

If suitable innovation management is adopted in power marketing and management, the cost of power marketing and management can be greatly reduced, improving the quality of power marketing and management. Therefore, innovation and management are of great importance to power marketing and management and even management of the entire power enterprises. With the progress and development of the times, innovation is an indispensable key force of social development. The development of all walks of life are inseparable from the dynamic support of innovation. In market economy environment, the development environment of power enterprises has changed a lot, traditional passive and conservative marketing and management mode cannot adapt to the actual demand of current social development nor ensure the stability of the entire power industry's development. Therefore, we must proceed from the perspective of power marketing management, comprehensively enhance innovation of power enterprises' management mode so as to achieve long-term and stable development of power enterprises in the current fierce competition.

\section{References}

[1] J.J Zhang, Si-Qi H E. The Economy Analysis of Regional Electric Power Marketing[J]. China Electric Power, 2011.

[2] Q.Y Xiao, Power marketing service management technology research[J]. Hunan Agricultural Machinery, 2012.

[3] L.U Xi-Jing, Construction of Intelligent Power Marketing Distribution Information System in Nanning Power Supply Bureau[J]. Guangxi Electric Power, 2011, 18(4):1879-90.

[4] X.T Dai, R.S Chen and B Xiao, Application of decision tree mining algorithms based on information entropy in the intelligent electric power marketing[J]. Journal of Zhengzhou University of Light Industry, 2012. 
[5] L Feng, X.S Feng, Brief Analysis on the Situation and Development Countermeasure of Modern Electric Power Marketing[J]. China Electric Power, 2012.

[6] J.X Long, Implementation of Decision Support System for Electric Power Marketing[J]. Applied Mechanics \& Materials, 2011, 63-64:168-171.

[7] H.F Chen, J Zhu and L.I Wei-Hua, Application effectiveness of energy metering automation systems in electric power marketing[J]. Power Demand Side Management, 2011.

[8] L.I Yan, Z.Q Zhang, Exploration of New Ways to Electric Power Marketing Management[J]. Journal of Anhui Electrical Engineering Professional Technique College, 2011.

[9] D.A Li, brief talk on how to strengthen the power marketing management in power supply enterprises[J]. Technological Development of Enterprise, 2011.

[10] Tewksbury D G, Lim S S and Su G. New Chapters in the Mobile-Sierra Story: Application of the Doctrine after NRG Power Marketing, LLC v Marine Public Utilities Commission[J]. Energy Law Journal, 2011, 32.

[11]C.Z Wei, Discussion on Power Marketing Management Methods for Power Supply Enterprise[J]. Value Engineering, 2010.

[12] L.I Xiao-Ya, L.I Yong and X Mao, et al. Discussion on the expansion of the power marketing inspection work[J]. Power Demand Side Management, 2010. 